University of Nebraska - Lincoln

DigitalCommons@University of Nebraska - Lincoln

1986

\title{
Effect of Dry, High-Moisture and Reconstituted Normal and High- Lysine Corn Diets and Particle Size on Energy and Nitrogen Metabolism in Growing Swine
}

\author{
G. L. Asche \\ University of Nebraska-Lincoln \\ J. D. Crenshaw \\ North Dakota State University \\ A. J. Lewis \\ University of Nebraska-Lincoln, alewis2@unl.edu \\ E. R. Peo, Jr. \\ University of Nebraska-Lincoln
}

Follow this and additional works at: https://digitalcommons.unl.edu/animalscifacpub

Part of the Animal Sciences Commons

Asche, G. L.; Crenshaw, J. D.; Lewis, A. J.; and Peo, Jr., E. R., "Effect of Dry, High-Moisture and Reconstituted Normal and High-Lysine Corn Diets and Particle Size on Energy and Nitrogen Metabolism in Growing Swine" (1986). Faculty Papers and Publications in Animal Science. 678.

https://digitalcommons.unl.edu/animalscifacpub/678

This Article is brought to you for free and open access by the Animal Science Department at DigitalCommons@University of Nebraska - Lincoln. It has been accepted for inclusion in Faculty Papers and Publications in Animal Science by an authorized administrator of DigitalCommons@University of Nebraska - Lincoln. 


\title{
EFFECT OF DRY, HIGH-MOISTURE AND RECONSTITUTED NORMAL AND HIGH-LYSINE CORN DIETS AND PARTICLE SIZE ON ENERGY AND NITROGEN METABOLISM IN GROWING SWINE ${ }^{1,2}$
}

\author{
G. L. Asche, J. D. Crenshaw ${ }^{3}$, A. J. Lewis and E. R. Peo, Jr. ${ }^{4}$ \\ University of Nebraska ${ }^{5}$ \\ Lincoln 68583-0908
}

\begin{abstract}
Two metabolism studies were conducted with 24 (Exp. 1) and 36 (Exp. 2) crossbred barrows (initial weight $35 \mathrm{~kg}$ ) to determine the effect of corn type - normal corn (NC) and high-lysine corn (HLC) - and storage method - dry (D), high-moisture (HM) and reconstituted (RC) - on energy and $\mathrm{N}$ digestibility. Diets fed in Exp. 1 were: 1 , NC-soybean meal formulated at $.78 \%$ lysine (dry matter basis); 2, HLC-soybean meal containing the same amount of corn as diet 1 ( $87 \%$ lysine); 3 , HLC-soybean meal with the same lysine level as diet 1. In Exp. 1, dry matter, energy and $\mathrm{N}$ digestibilities were not different between corn types or lysine levels $(P>.16)$. These results indicate that energy and N digestibility of HLC in typical diets for growing swine are similar to those for NC diets when both are balanced on a lysine basis. Also, replacing NC with HLC on an equal-weight basis did not affect energy and $\mathrm{N}$ digestibility. In Exp. 2 six diets balanced on an isonitrogenous and dry-matter basis were tested. Normal corn and HLC diets, which had been stored by three different methods $(D, H M$ and $R C)$ were arranged in a $2 \times 3$ factorial plan. There were no differences between corn types in dry matter, energy and $\mathrm{N}$ digestibilities. The HM and RC treatments had larger particle sizes than the dry corn diets. For diets balanced on an isonitrogenous basis, dry corn storage improved energy digestibility $(P<.10)$. Reconstitution appeared to improve energy balance and $\mathrm{N}$ digestibility of HLC, while HM storage improved energy balance and $N$ digestibility of $\mathrm{NC}$.
\end{abstract}

(Key Words: Pigs, Maize, Lysine, Moisture Content, Reconstitution, Digestibility.)

\section{Introduction}

Since the discovery of the opaque- 2 gene, the superior nutritional quality of high-lysine corn (HLC) compared with normal corn (NC) for swine has been demonstrated by numerous researchers (Beeson et al., 1966; Cromwell et al., 1967; Gipp and Cline, 1972).

The digestibility of HLC was investigated in balance trials by Cromwell et al. (1969). Their data indicated that HLC protein was more digestible and had a higher biological value than

\footnotetext{
${ }^{1}$ Published as Paper No. 7924, Journal Series, Nebraska Agr. Exp. Sta. Research reported was conducted under Projects 13-011 and 13-052.

${ }^{2}$ The technical assistance of Mary B. Barnes, Joy L. Kovar and Roy I. Carlson is gratefully acknowledged. Thanks is also extended to Diana J. Smith for preparation of the manuscript.

${ }^{3}$ Present address: Dept. of Anim. Sci., North Dakota State Univ., Fargo, 58105.

${ }^{4}$ To whom reprint requests should be addressed.

${ }^{5}$ Dept. of Anim. Sci.

Received October 28, 1985.

Accepted February 11, 1986.
}

NC protein. Using various levels of soybean meal, Sihombing et al. (1969) and Marroquin et al. (1973) reported that the $\mathrm{N}$ digestibility of HLC was higher than that of NC. Rosa et al. $(1977 \mathrm{a}, \mathrm{b})$ evaluated $\mathrm{N}$ and energy metabolism of rats and pigs fed NC and HLC mutants. Nitrogen digestibility and retention were not different, while biological value of $\mathrm{N}$ was higher for HLC diets fed to rats. Energy digestibility of HLC was lower than NC for both rats and pigs.

Previous research on the digestibility of HLC has been conducted with opaque-2 single and double mutants, but the new, higher-yielding varieties of HLC have not been examined. There are few data available on the energy and $\mathrm{N}$ digestibilities of high moisture (HM) and reconstituted (RC) NC and HLC. In one study, Sachtleben et al. (1975) reported that the energy digestibility of dry (D) and HM-NC and HM-HLC was similar in swine.

The purpose of the present research was to determine dry matter digestibility, energy and $\mathrm{N}$ metabolism of NC and HLC for growing swine fed 1) diets balanced on a lysine basis, 
and diets where HLC replaced NC on an equalweight basis and 2) D, HM and RC diets balanced on an isonitrogenous basis.

\section{Experimental Procedure}

Exp. 1. Twenty-four crossbred barrows (initial weight $35 \mathrm{~kg}$ ) were allotted to three dietary treatments. The amino acid compositions of the corns and soybean meal used in Exp. 1 and Exp. 2 were the same as those reported previously (Asche et al., 1985). The three dietary treatments contained dry, rolled corn fed in a meal form. Diet 1 was a NCsoybean meal diet formulated to contain $.78 \%$ lysine (dry matter basis). Diet 2 was a HLCsoybean meal diet than contained the same amount of corn as diet 1 and contained .87\% lysine. Diet 3 was a HLC-soybean meal diet, formulated to contain the same amount of lysine as diet 1 . The compositions of the three diets are presented in table 1.

The pigs were divided into two groups of 12 , and housed in an environmentally controlled room. Ad libitum intakes were determined by feeding the pigs the dietary treatments for a 5-d preliminary period. The pigs were individually housed in $1-\times 1.5-\mathrm{m}$ pens containing plasticcoated, mesh floor and nipple waterers. Then, the pigs were moved for a 5 -d adaptation period to raised, adjustable, circular metabolism crates containing expanded-metal floors and nipple waterers. The crate design allowed separate collection of urine, feces and orts. All pigs, while in the metabolism crates, were restricted to $90 \%$ of the lowest preliminary ad libitum intake. In this way, the same restricted amount of feed was offered to all pigs during adaptation and collection. All pigs were similar in weight at the start of the feeding regimen (range 29.0 to $33.6 \mathrm{~kg}$ ), therefore, feed intake per $\mathrm{kg}$ of body weight was nearly constant. Urine, feces and orts were collected for $5 \mathrm{~d}$.

Daily urine collections were acidified with $100 \mathrm{ml}$ of a $10 \%(\mathrm{v} / \mathrm{v})$ solution of technical grade concentrated hydrochloric acid and diluted to the nearest $500 \mathrm{ml}$ with distilled water. The diluted urine was mixed and a $1 \%$ subsample of the daily volume was withdrawn and stored at $-20 \mathrm{C}$ until analyzed. Daily feces and orts were also frozen. After collections were completed, the feces from

\footnotetext{
${ }^{6}$ Solka floc, Product of Brown Co., Berlin, NH.
}

each pig were thawed at room temperature, thoroughly mixed and weighed. A subsample was freeze-dried for analysis of $\mathrm{N}$ and gross energy and a portion was retained for dry matter determination.

Analysis of feed, feces and urine for $\mathrm{N}$ was by the Kjeldahl method (AOAC, 1980). An adiabatic oxygen bomb calorimeter was used for gross energy determination of the same samples. Approximately $1 \mathrm{~g}$ of feed and feces and $4 \mathrm{ml}$ of urine were used for $\mathrm{N}$ and energy analyses.

For gross energy determination, ground, dry feed and feces were pressed into a pellet before being placed in a combustion capsule. Urine was pipetted onto $1 \mathrm{~g}$ of cellulose ${ }^{6}$ carrier. The prepared urine samples were allowed to dry at room temperature for $36 \mathrm{~h}$. After air drying, the gross energy of the cellulose + urine samples was determined. The energy content of the urine was calculated by subtracting the average gross energy analysis of three cellulose samples. Orts were dried and their dry weight subtracted from the dry matter intake of each pig.

Exp. 2. Thirty-six crossbred barrows (initial weight $35 \mathrm{~kg}$ ) were allotted to six dietary treatments in a $2 \times 3$ factorial arrangement consisting of two corn types (NC and HLC) and three storage methods (D, HM and RC). The diets were calculated on an isonitrogenous, equivalent dry-matter basis, using the same sources of corn as Exp. 1. The six corn $x$ storage types were ground in a hammermill $(2.54-\mathrm{cm}$ screen) before mixing into the diets. Harvesting and storage of the $\mathrm{HM}$ and RC corn was the same as described by Crenshaw et al. (1984). The composition of the diets used in Exp. 2 is presented in table 1.

The pigs were fed ad libitum the assigned dietary treatments during a 5-d preliminary period, and then given a daily amount of feed that was equal to $5 \%$ of their body weight ${ }^{90}$ (converted from dry to as-fed basis) during a 3-d adjustment to the metabolism crates, and followed by a $5-\mathrm{d}$ collection of urine, feces and orts. Other procedures and analyses were similar to those described for Exp. 1.

The particle size distributions of the prepared corns used in both experiments were characterized for modulus of uniformity, modulus of fineness (Agricultural Engineers Yearbook, 1962; Pfost, 1976) and particle size profile by mechanically sifting the corn through a series of standard sieves. 


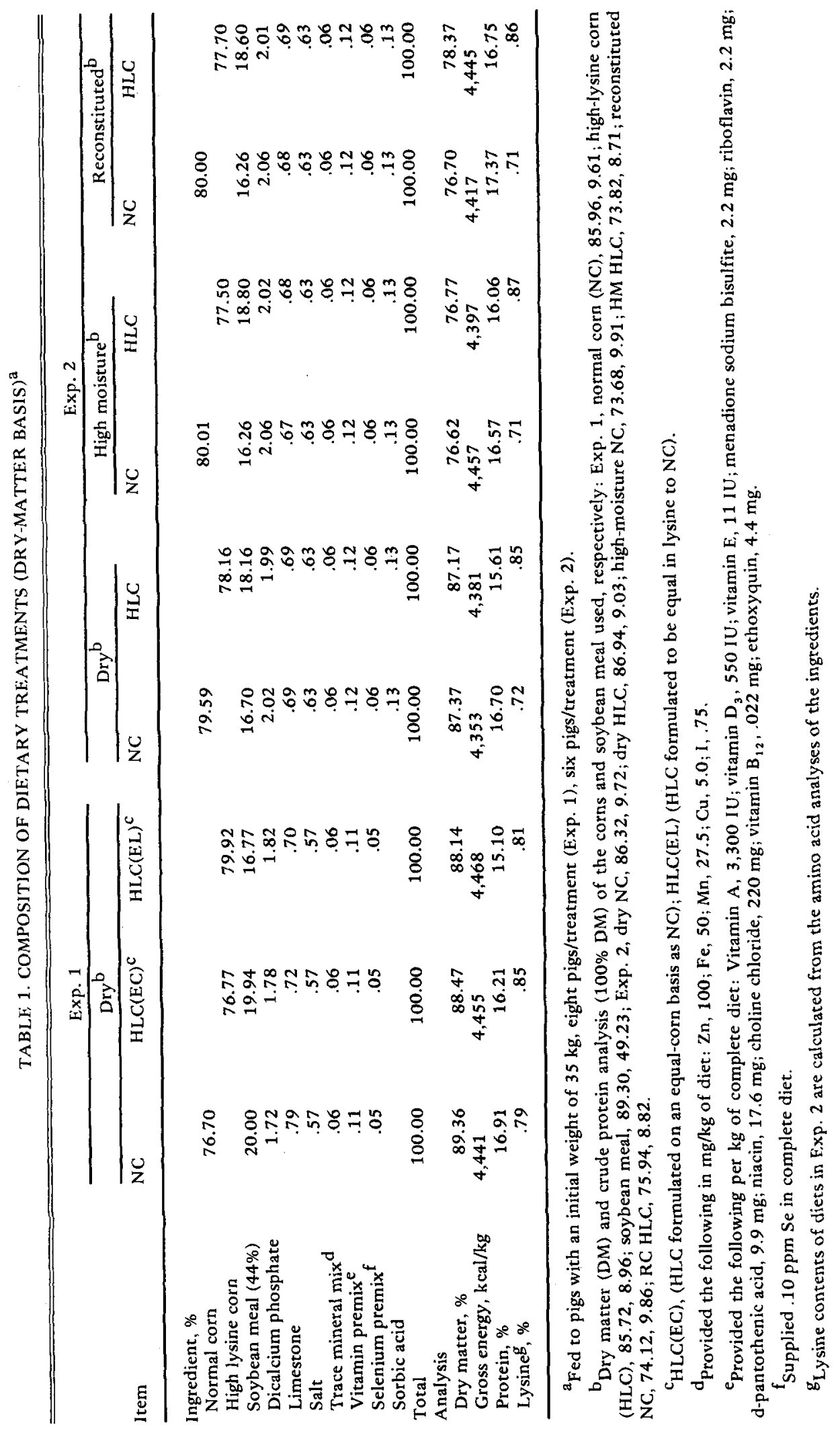


Statistical analysis of both experiments was by analysis of variance procedures for a randomized complete-block design with orthogonal treatment comparisons (Exp. 1 and 2), and a factorial arrangement of treatments using the main effects of com type and storage method and their interactions (Exp. 2) as described by Steel and Torrie (1980). Initial weight of the pigs was used as a covariate in Exp. 2 and dry matter intake was used as a covarinte in both experiments. Analysis of variance was compured using the Statistical Analysis System (SAS, 1979).

\section{Resolts}

Exp. 1. The results of the sieve test (table 2) showed that rolled, dry NC was coarser than dry HLC when measured by both modalus of uniformity and modulus of fineness.

Dry matter digestibility (table 3) was not different ( $P>$.24) among treatments. Gross energy intake (table 4) was lower for the NC diet than the HLC diets $(P<.001)$ and also lower for the HLC diet formulated to contain the same amount of corn as the NC diet com- pared with the HLC diet that was formulated on an equalhysine basis $(P<.10)$. Apparent digessible energy was not different (P>.17) among treatments. Apparent metabolizable energy and energy balance were slightly lower in the HLC diet formulated to contain the same amount of com as the NC diet than in the HLC. diet formulated on an equal-lysine basis $(\mathbf{P}<.10)$.

Intake of N (table 5) was higher for the NC diet than the HLC diets and was higher for the HLC diet formulated on an equal-com basis than for the diet formulated on an equal-tysine basis $(P<.001)$. This reflected the differences in crude protein analyses of the diets (table 1 ) and was a consequence of the objectives of the experiment. Nitrogen digestibility and $\mathbf{N}$ balance were not affected by treatment $(P>$.24). In contrast, $N$ retention and apparent biological value were higher for the diet equal in lysine to the $\mathrm{NC}$ diet than for the diet formulated by equal replacement of corn $(P<.10)$, even though the latter had higher lysine and protein contents.

Exp. 2. The results of the sieve test (table 2) comparing corn type and storage method

TABLE 2. EFFECT OF CORN TYPE AND STORAGE METHOD ON MODULUS OF UNIFORMITY, MODULUS OF FINENESS AND PARTICLE SIZE PROFILE

\begin{tabular}{|c|c|c|c|c|c|c|c|c|}
\hline \multirow[b]{3}{*}{ Criterion } & \multirow{2}{*}{\multicolumn{2}{|c|}{$\frac{\text { Exp. } 1^{2}}{\text { Rolled }}$}} & \multicolumn{6}{|c|}{ Exp. $2^{2}$} \\
\hline & & & \multicolumn{6}{|c|}{ Ground corn samples } \\
\hline & DNC & DHLC & DNC & D-HLC & HMHC & HMHLC & RC-NC & RC-HLC \\
\hline $\begin{array}{l}\text { Modulus of uniformity } \\
\text { Modulus of fineness }\end{array}$ & $\begin{array}{r}8: 2: 0 \\
6.21\end{array}$ & $\begin{array}{c}7: 2: 1 \\
5.90\end{array}$ & $\begin{array}{r}4: 4: 2 \\
4.41\end{array}$ & $\begin{array}{r}3: 3: 4 \\
3.71\end{array}$ & $\begin{array}{r}5: 2: 3 \\
4,58\end{array}$ & $\begin{array}{r}5: 3: 2 \\
4.95\end{array}$ & $\begin{array}{r}5: 2: 3 \\
4.78\end{array}$ & $\begin{array}{r}4: 2: 4 \\
4.20\end{array}$ \\
\hline 3,360 & 13.3 & 7.4 & 2.4 & 3.1 & 17.3 & 18.0 & 15.7 & 12.9 \\
\hline 1,650 & 49.8 & 53.9 & 18.8 & 14.5 & 23.5 & 26.6 & 26.9 & 227 \\
\hline 1,190 & 13.7 & 11.3 & 15.1 & 11.6 & 6.0 & 7.0 & 7.8 & 6.6 \\
\hline 840 & $\mathbf{8 . 3}$ & 7.6 & 14.8 & 10.7 & 5.4 & 6.1 & 6.3 & 5.7 \\
\hline 500 & 5.7 & 5.6 & 14.3 & 10.8 & 6.4 & 7.7 & 6.7 & 6.5 \\
\hline 350 & 4.4 & 4.8 & 13.3 & 12.4 & 9.8 & 11.4 & 7.9 & 7.6 \\
\hline 250 & 2.3 & 3.1 & 9.2 & 126 & 10.6 & 8.0 & 10.3 & 8.7 \\
\hline 105 & 2.0 & 4.6 & 9.6 & 15.8 & 15.7 & 10.9 & 14.3 & 23.2 \\
\hline Residual & -5 & 1.7 & 2.5 & 8.5 & 5.3 & 4.3 & 4.1 & 6.1 \\
\hline
\end{tabular}

2D-NC (dry, normal corn); D-HLC (dry, highlysine corn); HMHC (high-moisture NLC); RC-NC (reconstituted NC).

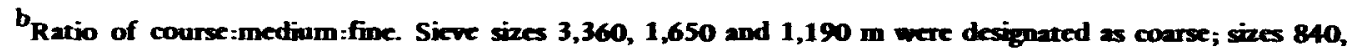
500 and $350 \mathrm{~m}$ were designated as medium and sizes $250,105 \mathrm{~m}$ and residual were designated as fine.

Degree of fineness of the sample determined by a weighted sum of the percentage of material remaining on each sieve. The largest sicve size was designated as 8 and the residual was designated as 0 .

dVahes are the percentage of a $50 \mathrm{~g}$ com sample retained on top of sieves after 5 min of shaking on a Soiltest Sieve Shaker, Modd CL-932B. 
TABLE 3. EFFECT OF CORN TYPE ANDSTORAGE METHOD ON DRY MATTER INTAKE AND DRY MATTER DIGESTIBULJTYª

\begin{tabular}{|c|c|c|}
\hline Treatment & $\begin{array}{l}\text { Dry matter } \\
\text { intake } 5 \text {, g/d }\end{array}$ & $\begin{array}{l}\text { Dry matter } \\
\text { digexibiliky }, x\end{array}$ \\
\hline \multicolumn{3}{|l|}{ Exp. 1} \\
\hline D-NC & 1,453 & 86.03 \\
\hline D-HLC(EC) & 1,436 & 84.85 \\
\hline D-HLC(EL) ${ }^{d}$ & 1,430 & 85.71 \\
\hline $\mathrm{CV}^{e}, \times$ & .64 & 1.57 \\
\hline \multicolumn{3}{|l|}{ Exp. 2} \\
\hline D-NC & 1,064 & 85.99 \\
\hline D-HLC & 1,075 & 85.90 \\
\hline HMNC & 1,065 & 84.41 \\
\hline HMHLC & 1,064 & 84.46 \\
\hline RC-NC & 1,051 & 84.40 \\
\hline RC-HLC & 1,059 & 86.00 \\
\hline $\mathrm{CV}^{e}, \%$ & 1.33 & 1.23 \\
\hline
\end{tabular}

\footnotetext{
Treatment means adjusted using dy matter intake of the pigs as a covariate in both experiments and initial weight in Exp. 2; Exp. 1, cight pizftureatment; Exp. 2, six pisstureatment.

bMeans and CV before covariate amalysis; means when dry matter intake was used as a covariate, Exp. 1, 1,400 and Exp. 2, 1,063 g/d. Exp. 1, DNC vs DHLC(EC) and DHLC(EL) $(\mathbf{P}<.001)$.

Fxp. 2, D w HM and RC storge methods (P<10).

dD-HLC(EC), (dry, hightysine com formulated on an equat-corn basis with normal corn); D-HLC(EL), (dry, high-lysine corn formulated to be equal in lysine to DNC).

Coefficient of variation.
}

showed that particle size was smaller for the D than the HM or RC corns for both NC and HLC. The DHLC was ground to a finer particle size than the D-NC, as shown by the modulus of uniformity (less coarse particles and more fine material) and the smaller modulus of fineness. Of the fermented corn, HM-NC contained less coarse and more fine material than HM-HLC, as seen by the modulus of uniformity and particle size profile. The opposite was true for the RC corns; RC-HLC had fewer coarse particles and more fine particles than RC-NC.

Dry matter digestibility (table 3) was higher for D than HM and RC storage methods $(P<.10)$. Gross energy intake was lower for $D$ than HM and RC corns ( $<<.001$; table 4).

$A$ corn type $X D$ vs HM and RC storage methods interaction was also detected for gross energy intake $(\mathbf{P}<.001)$. An interaction between corn type and HM vs RC storage methods
$(P<.02)$ was detected for gross energy intake, digestible energy, metabolizable energy and energy balance.

The intake of $\mathbf{N}$ was higher for NC diets than HLC diets $(P<.001)$, higher for HM and RC diets than $D$ diets $(P<.05)$ and higher for $R C$ diets than HM diets ( $(P<.01$; table 5). Two corn type $x$ storage method interactions were detected for $\mathbf{N}$ intake. Corn type interacted with $D$ vs $H M$ and $R C$ storage methods $(P<.01)$ and HM vs RC storage methods $(P<.10)$ for $N$ intake. In addition, $\mathbf{N}$ digestibility was higher for $\mathrm{HM}$ and $\mathrm{RC}$ treatments than the $\mathrm{D}$ corn treatments $(P<.05)$. High moisture and RC scorage methods interacted with corn type $(P<10)$ for $N$ digestibility and $N$ balance. The remaining $N$ criteria were not affected by the treatments.

\section{Discussion}

Differences Due To Com Type. Regardless of whether diets were balanced on a lysine (Exp. 1) or protein basis (Exp. 2), dry matter, energy and $\mathbf{N}$ digestibilities were not different between NC and HLC. Marroquin et al. (1973) observed no differences in dry matter digestibility for HLC and NC, while Rosa et al. (1977a) and Cromwell et al. (1969) reported that dry matter digestibility of HLC was lower than NC. In contrast, Sihombing et al. (1969) reported that HLC tended to have a higher dry matter digestibility than NC.

Rosa et al. (1977a) reported that HLC had a lower digestible energy content than NC for both rats and pigs. In the present experiments there were no differences in digestible and metabolizable energy values between NC and HI.C.

The similarities in $\mathbf{N}$ digestibility between NC and HLC reported by Mertz et al. (1965) are supported by the results of the experiments reported herein. Marroquin et al. (1973) and Sachuleben et al. (1975) have reported that $\mathbf{N}$ digestibility was higher for pigs fed HLC diets than for those fed NC diets. Cromwell et al. (1969) reported that HLC supported greater N retention in 31- and $57-\mathrm{kg}$ pigs that were fed isonitrogenous diets, or diets containing the same amounts of NC or HLC. In Exp. 1, N balance was influenced primarily by the difference in $\mathbf{N}$ intake because the diets were not isonitrogenous. Nitrogen digestibility tended to be higher for the HLC diets. The diets formulated on an equal-Hysine basis had similar $N$ 
TABLE 4. EFFECT OF CORN TYPE AND STORAGE METHOD ON ENERGY METABOLISM ${ }^{\mathrm{a}}$

\begin{tabular}{|c|c|c|c|c|}
\hline Treatment & $\begin{array}{l}\text { Gross energy } \\
\text { intake bcdefg, } \\
\mathrm{kcal} / \mathrm{d}\end{array}$ & $\begin{array}{l}\text { Apparent } \\
\text { digestible } \\
\text { energy }, \mathrm{kcal} / \mathrm{kg}\end{array}$ & $\begin{array}{l}\text { Apparent } \\
\text { metabolizable } \\
\text { energy }{ }^{\mathrm{cg}}, \mathrm{kcal} / \mathrm{kg}\end{array}$ & $\begin{array}{l}\text { Energy } \\
\text { balance cgh } \\
\text { kcal/d }\end{array}$ \\
\hline \multicolumn{5}{|l|}{ Exp. 1} \\
\hline D-NC & 6,394 & 3,756 & 3,657 & 5,263 \\
\hline D-HLC(EC) & 6,414 & 3,698 & 3,589 & 5,165 \\
\hline D-HLC(E L) & 6,434 & 3,749 & 3,653 & 5,259 \\
\hline $\mathrm{CV}^{\mathrm{i}}, \%$ & .01 & 1.80 & 1.78 & 1.78 \\
\hline \multicolumn{5}{|l|}{ Exp. 2} \\
\hline D-NC & 4,634 & 3,692 & 3,574 & 3,801 \\
\hline D-HLC & 4,657 & 3,681 & 3,561 & 3,788 \\
\hline HM-NC & 4,736 & 3,677 & 3,552 & 3,781 \\
\hline HM-HLC & 4,677 & 3,617 & 3,491 & 3,712 \\
\hline RC-NC & 4,697 & 3,630 & 3,513 & 3,736 \\
\hline RC-HLC & 4,726 & 3,727 & 3,593 & 3,817 \\
\hline $\mathrm{CV}^{\mathrm{i}}, \%$ & .14 & 1.56 & 1.60 & 1.62 \\
\hline
\end{tabular}

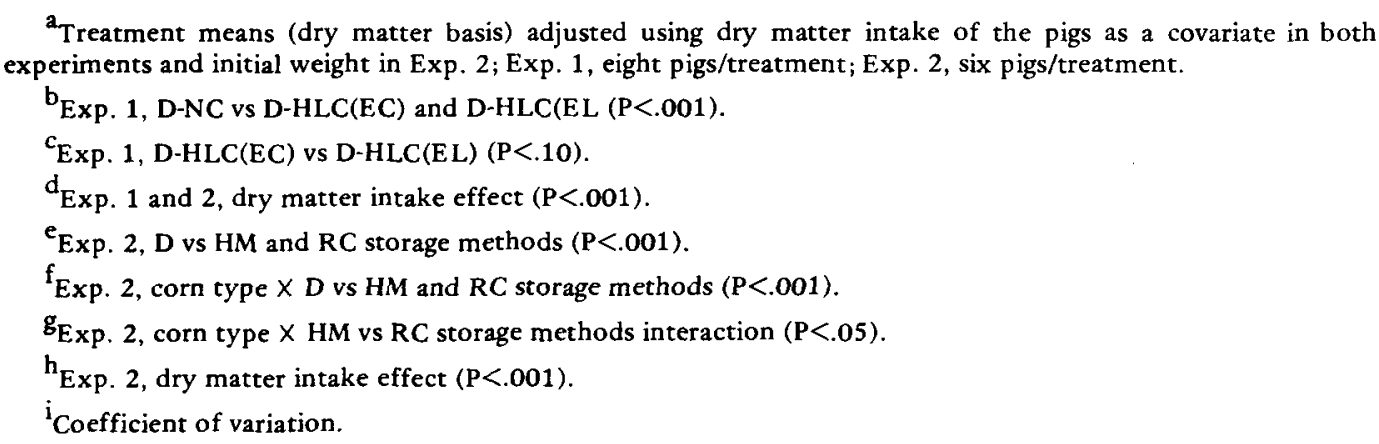

metabolism patterns irrespective of corn type. This is in agreement with the data of Cromwell et al., (1969) and Rosa et al. (1977b).

The present data exhibit similar trends when comparing high lysine and normal corn on an equal-lysine basis and between corn types. However, in Exp. 1, when comparing diets with equal additions of NC and HLC, the NC diet tended to support higher biological value and $\mathrm{N}$ balance than the HLC diet. This may imply that the additional lysine supplied from the HLC was not utilized by the pig. This implies that there is no benefit to replacing NC corn with an equal content of HLC when formulating diets for growing pigs.

Numerous experiments have shown that the superiority of opaque-2 corn is due to its improved amino acid balance (Mertz et al., 1964; Nelson et al., 1965; Nelson 1966; Cromwell et al., 1967). It was clearly shown (Exp. 1) that HLC diets balanced on a lysine basis were similar to the NC diets in dry matter, energy and $\mathrm{N}$ digestibilities.
Differences Due To Storage Metbod. Dry matter digestibility was lower for HM than D and RC diets. Goodrich et al. (1975) found higher dry matter losses in fermented HM grain than in fermented RC grain. The HM corn used in this experiment was harvested earlier than the $\mathrm{D}$ corn and also was fermented longer than the $\mathrm{RC}$ corn.

Digestible and metabolizable energy and energy balance were higher for D than HM and RC storage methods. This indicates that fermentation of the HM and RC corn did not improve energy utilization. Bergen (1976) reported that lactic acid increased and $\mathrm{pH}$ decreased as a result of anaerobic microbial fermentation of soluble carbohydrates. Danley and Vetter (1974a) also reported higher soluble carbohydrates and lower butyrate levels in ensiled than D corn. Goodrich et al. (1975) reported that RC corn produced less volatile gases, maintained a higher $\mathrm{pH}$ and therefore less fermentation than HM corn. In contrast to the present data, Sachtleben et al. (1975) found 
TABLE 5. EFFECT OF CORN TYPE AND STORAGE METHOD ON NITROGEN METABOLISM ${ }^{\mathrm{a}}$

\begin{tabular}{|c|c|c|c|c|c|}
\hline Treatment & $\begin{array}{l}\mathrm{N} \text { intake }{ }^{\text {bcdefghi }} \\
\mathrm{g} / \mathrm{d}\end{array}$ & $\begin{array}{l}\text { N digestibility }{ }^{\mathrm{fi}} \text {, } \\
\%\end{array}$ & $\begin{array}{l}\text { N retention } \mathrm{j}, \\
\%\end{array}$ & $\begin{array}{l}\text { Apparent } \\
\text { biological } \\
\text { value, } \%\end{array}$ & $\begin{array}{l}\text { N balance }{ }^{i} \\
g / d\end{array}$ \\
\hline \multicolumn{6}{|l|}{ Exp. 1} \\
\hline D-NC & 39.00 & 78.84 & 49.90 & 63.20 & 19.40 \\
\hline D-HLC(EC) & 37.43 & 79.53 & 47.81 & 60.09 & 17.86 \\
\hline D-HLC(EL) & 34.82 & 80.07 & 52.57 & 65.58 & 18.28 \\
\hline $\mathrm{CV}^{\mathbf{k}}, \%$ & .03 & 3.22 & 9.08 & 8.61 & 8.82 \\
\hline \multicolumn{6}{|l|}{ Exp. 2} \\
\hline D-NC & 27.96 & 80.91 & 42.29 & 52.18 & 11.79 \\
\hline D-HLC & 26.65 & 79.35 & 42.92 & 54.05 & 11.46 \\
\hline HM-NC & 28.29 & 83.02 & 44.52 & 53.60 & 12.60 \\
\hline HM-HLC & 27.30 & 80.29 & 44.03 & 54.77 & 12.01 \\
\hline RC-NC & 28.05 & 81.26 & 40.22 & 49.60 & 11.29 \\
\hline RC-HLC & 28.55 & 83.29 & 45.84 & 55.01 & 13.06 \\
\hline $\mathrm{CV}^{\mathrm{k}}, \%$ & 1.33 & 2.25 & 10.14 & 8.83 & 10.63 \\
\hline
\end{tabular}

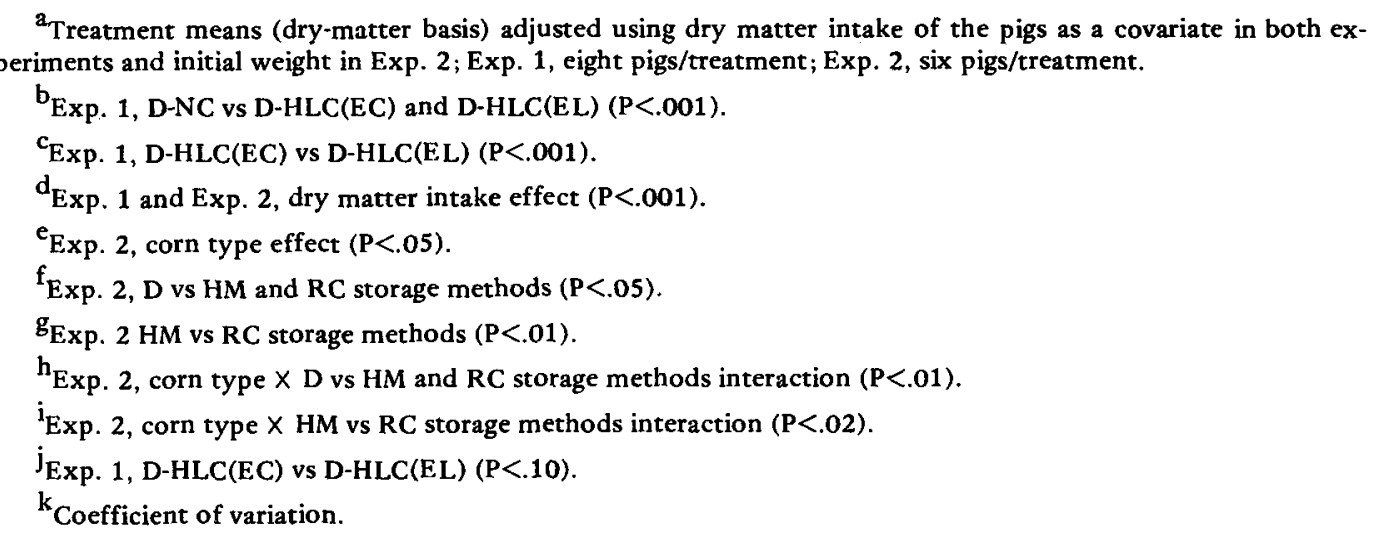

similar energy digestibilities among D-NC, HM-NC and HM-HLC diets fed to growing pigs.

The corn type $\times$ HM vs RC storage methods interaction for digestible energy, metabolizable energy and energy balance suggests that HM storage improved energy balance of NC and reconstitution improved energy balance of HLC.

Nitrogen digestibility was lower for $\mathrm{D}$ than HM or RC storage methods, which suggests that the fermentation process has a beneficial effect on $\mathrm{N}$ digestibility. Similar results were observed by Crenshaw et al. (1984) with pigs fed HMand RC-sorghum grain diets. In contrast, Sachtleben et al. (1975) reported lower N digestibility for HM-NC than D-NC and similar $\mathrm{N}$ digestibility for HM-HLC and D-NC. There were also differences between $H M$ and RC treatments for $\mathrm{N}$ digestibility, which caused a corn type $x$ storage method interaction. The highest $\mathrm{N}$ digestibility for $\mathrm{NC}$ diets occurred with the HM storage method, where-as reconstitution of corn improved $\mathrm{N}$ digestibility for pigs consuming HLC diets. This same trend is also apparent for $\mathrm{N}$ balance. Jones et al. (1970) found more soluble $\mathbf{N}$ in ensiled corn than dry corn, which may infer that attack by digestive enzymes would be more rapid. Danley and Vetter (1974b) compared the $\mathrm{N}$ fractions of $\mathrm{D}$, $H M$ and RC corn grain and found higher concentrations of soluble $N$ in ensiled (HM and RC) than in D corn storage. Also, small but nonsignificant increases in water and $\mathrm{NaCl}$ soluble $\mathrm{N}$ for RC vs HM corn storage methods were reported. Similar differences in the quantities of soluble $\mathrm{N}$ between RC and HM corn could explain some of the $\mathrm{N}$ metabolism results obtained in Exp. 2.

Differences in particle size distributions between the corn types may partially explain the interaction of HM and RC storage methods with corn type for energy and $\mathrm{N}$ characteristics. 
The higher energy balance and $\mathrm{N}$ digestibility of HM-NC and reconstituted HLC may be related to the smaller particle size of the HM-HLC and RC-NC. Recent data have shown improved energy and $\mathrm{N}$ digestibility as particle size decreased for pigs fed sorghum grain (Owsley et al., 1981) and corn and sorghum grain (Ohh et al., 1983).

The results of these experiments indicate that energy and $\mathrm{N}$ digestibility are similar between NC and HLC diets for growing swine whether the diets are balanced on an equivalent lysine or protein basis. The substitution of HLC for NC on an equal-weight basis is not beneficial based on energy and $\mathrm{N}$ metabolism. Diets fed in a dry form favored improvements in energy digestibility whereas $\mathrm{HM}$ and $\mathrm{RC}$ diets had improved $\mathrm{N}$ digestibility. Energy balance and $\mathrm{N}$ digestibility was improved for NC stored as HM grain and for HLC stored as RC grain.

\section{Literature Cited}

Agricultural Engineers Yearbook. 1962. Method of determining modulus of uniformity and modulus of fineness of ground feed. p 249.

AOAC. 1980. Official Methods of Analysis (13th Ed.). Association of Official Analytical Chemists, Washington, DC.

Asche, G. L., A. J. Lewis, E. R. Peo, Jr. and J. D. Crenshaw. 1985. The nutritional value of normal and high lysine corns for weanling and growingfinishing swine when fed at four lysine levels. J. Anim. Sci. 60:1412.

Beeson, W. M., R. A. Pickett, E. T. Mertz, G. L. Cromwell and O. E. Nelson. 1966. Nutritional value of high lysine corn. Proc. Distillers Feed Res. Conf., Cinncinnati, OH. p 70.

Bergen, W. G. 1976. Utilization of nitrogen from fermented feeds. Oklahoma State Univ. Symp. on High-Moisture Grains.

Crenshaw, J. D., E. R. Peo, Jr., A. J. Lewis, B. D. Moser and T. D. Crenshaw. 1984. The nutritional value of high moisture and reconstituted sorghum grain for swine. J. Anim. Sci. 58:1222.

Cromwell, G. L., R. A. Pickett and W. M. Beeson. 1967. Nutritional value of opaque-2 corn for swine. J. Anim. Sci. 26:1325.

Cromwell, G. L., R. A. Pickett, T. R. Cline and W. M. Beeson. 1969. Nitrogen balance and growth studies of pigs fed opaque-2 and normal corn. J. Anim. Sci. 28:478.

Danley, M. M. and R. L. Vetter, 1974a. Artificially altered corn grain harvested at three moisture levels. 1. Dry matter and nitrogen losses and changes in the carbohydrate fractions. J. Anim. Sci. 38:417.

Danley, M. M. and R. L. Vetter. 1974b. Artificially altered corn grain harvested at three moisture levels. II. Changes in the nitrogen fractions. $\mathrm{J}$. Anim. Sci. 38:424.

Gipp, W. F. and T. R. Cline. 1972. Nutritional studies with opaque-2 and high protein opaque- 2 corns. J. Anim. Sci. 34:963.

Goodrich, R. D., F. M. Beyers and J. C. Meiske. 1975. Influence of moisture content, processing and reconstitution on the fermentation of corn grain. J. Anim. Sci. 41:876.

Jones, G. M., E. Donefer and J. I. Elliot. 1970. Feeding value for dairy cattle and pigs of high moisture corn preserved with propionic acid. Can. J. Anim. Sci. 50:483.

Marroquin, C. R., G. L. Cromwell and V. W. Hays. 1973. Nutritive value of several varieties of opaque- 2 corn and normal corn for growing swine. J. Anim. Sci. 36:253.

Mertz, E. T., L. S. Bates and O. E. Nelson. 1964. Mutant gene that changes protein composition of maize endosperm. Science 145:279.

Mertz, E. T., O. A. Veron, L. S. Bates and O. E. Nelson. 1965. Growth of rats fed on opaque-2 maize. Science 148:1741.

Nelson, O. E. 1966. Mutant genes that change the composition of maize endosperm proteins. Fed. Proc. 25:1676.

Nelson, O. E., E. T. Mertz and L. S. Bates. 1965. Second mutant gene affecting the amino acid pattern of maize endosperm proteins. Science 150:1469.

Ohh, S. J., G. Allee, K. C. Behnke and C. W. Deyoe. 1983. Effect of particle size of corn and sorghum grain on performance and digestibility of nutrients for weaned pigs. J. Anim. Sci. 57(Suppl. 1):260.

Owsley, W. F., D. A. Knabe and T. D. Tanksley, Jr. 1981. Effect of sorghum particle size on digestibility of nutrients at the terminal ileum and over the entire digestive tract of growing-finishing swine. J. Anim. Sci. 52:557.

Pfost, H. B. 1976. Feed Manufacturing Technology. Amer. Feed Manufacturers Assoc., Arlington, VA.

Rosa, J. G., D. M. Forsyth, D. V. Glover and T. R. Cline. 1977a. Normal, opaque-2, waxy, waxy opaque- 2 , sugary- 2 and sugary- 2 opaque- 2 corn endosperm types for rats and pigs. Studies on energy utilization. J. Anim. Sci. 44:1004.

Rosa, J. G., D. M. Forsyth, D. V. Glover and T. R. Cline. 1977b. Normal, opaque-2, waxy, waxy opaque-2, sugary-2 and sugary-2 opaque-2 corn endosperm types for rats and pigs. Studies on protein quality. J. Anim. Sci. 44:1011.

Sachtleben, S. S., E. R. Miller and H. E. Henderson. 1975. Waxy, high lysine and normal corn for swine. J. Anim. Sci. 41:328. (Abstr.).

SAS. 1979. SAS User's Guide. Statistical Analysis System Institute, Inc., Cary, NC.

Sihombing, D.T.H., G. L. Cromwell and V. W. Hays. 1969. Nutritive value and digestibility of opaque-2 and normal corn for growing pigs. J. Anim. Sci. 29:921.

Steel, R.G.D. and J. H. Torrie. 1980. Principles and Procedures of Statistics (2nd Ed.). McGraw-Hill Book Co., New York, NY. 